\title{
Formuły trynitarne we wschodnich i zachodnich modlitwach eucharystycznych
}

Sakramenty chrztu i Eucharystii, pierwszy wprowadzający do życia chrześcijańskiego, a drugi stanowiący jego zasadę i pełnię, stanowią ośrodek liturgii Kościoła, gdyż są uroczystą celebracją tajemnicy wiary jako źródła ożywiającej i udoskonalającej łaski Bożej, określającą jej specyfikę i znaczenie oraz wskazują na te treści, które stanowią kluczowy punkt odniesienia dla całej liturgii Kościoła i życia wszystkich wierzących. Fakt ten widać przede wszystkim w tym, że od samego początku istnienia Kościoła obrzędy chrztu i Eucharystii stanowią pierwsze i najważniejsze świadectwo wiary w Trójcę Świętą oraz są wyznaniem tej wiary'. Ta ogólna obserwacja wyznacza perspektywę niniejszego studium, w którym zamierzamy pokazać, w jaki sposób w liturgii następowała pewna ewolucja wiary w Trójcę Świętą i jak doszło do utrwalenia tej wiary w obecnej liturgii. Zamierza ono być także odpowiedzią na uwagę zwróconą przez recenzenta opublikowanego przeze mnie zbioru studiów trynitarnych Tajemnica Trójjedynego, według którego nie uwzględniłem w nich w wystarczającym stopniu teologii prefacji o Trójcy Świętej².

Por. J. Królikowski, Tajemnica Trójjedynego. Studia z teologii trynitarnej, Kraków 2015, S. $143-155$.

2 Por. P. Beyga, Recenzja, „Teologia w Polsce” 10 (2016) nr 1, s. 276. 


\section{Pierwotna wiara trynitarna w liturgii chrztu i Eucharystii}

Na podstawie Tradycji apostolskiej św. Hipolita Rzymskiego, która zawiera najstarszy opis obrzędu chrztu³, wiemy, że udzielanie tego sakramentu było integralnie połączone $z$ wyznaniem wiary opartym na udzieleniu odpowiedzi na trzy pytania dotyczące wiary w Ojca, Syna i Ducha Świętego: „Credis in Deum patrem omnipotentem? [...] Credis in Christum Iesum filium Dei? [...] Credis in Spiritu Sancto?"4.

W kanonie - uroczystej modlitwie eucharystycznej stanowiącej centrum liturgii rzymskiej - w tekście, którego zasadnicze sformułowania i treści sięgają końca IV wieku, a który przekazują manuskrypty z wieku viıI, znajdujemy formuły modlitewno-teologiczne, do których odwołujemy się do dnia dzisiejszego ${ }^{5}$. Prefacje mszalne, stanowiące element modlitw eucharystycznych, zaczynają się od wzniosłego wyznania: „Vere dignum et iustum est, aequm et salutare, nos tibi semper et ubique gratias agere: Domine sancte, Pater omnipotens, aeterne Deus: per Christum, Dominum nostrum"6. W doksologii kończącej kanon głosi się: „Per ipsum, et cum ipso, et in ipso, est tibi Deo Patri omnipotenti, in unitate Spiriitus Sancti, omnis honor et gloria" . Te zwarte formuły odzwierciedlają się szerzej i wyraźniej także w trzech zasadniczych „treściach” modlitwy eucharystycznej rozumianej jako całość literacko-treściowa: doksologia kieruje się do Boga Ojca, anamneza koncentruje się przede wszystkim na Jezusie Chrystusie, Synu Bożym, i na Jego dziele zbawczym, epikleza łączy się z Duchem Świętym i Jego działaniem. W tych trzech treściach, nawiązujących wyraźnie do dziejów zbawienia i do działania Trójcy Świętej w Kościele, trzeba widzieć najbardziej bezpośrednio trynitarny wymiar celebracji eucharystycznej. Poszczególne formuły i gesty są tylko jego podkreśleniem i pewnym uszczegółowieniem.

Zarówno w obrzędzie chrztu, jak i w uroczystej modlitwie eucharystycznej obecność trzech osób Bożych określa strukturę modlitwy, wskazując najpierw

3 Por. J. W. Boguniowski, Rozwój historyczny ksiąg liturgii rzymskiej do Soboru Trydenckiego i ich recepcja $w$ Polsce, Kraków 2001, s. 45-54.

4 Hipolit Rzymski, Traditio Apostolica, 21: sch 11, 84-86.

5 Por. J. A. Jungmann, Missarum solemnia. Eine genetische Erklärung der römischen Messe, Bd. 2, Wien-Freiburg-Basel 1962, s. 127-340; J. A. Jungmann, Liturgia pierwotnego Kościoła do czasów Grzegorza Wielkiego, przeł. T. Lubowiecka, Kraków 2013, s. 457-470.

6 Mszał rzymski z dodaniem nabożeństw nieszpornych, oprac. O. G. Lefebvre, przekład polski opracowali mnisi opactwa w Tyńcu, Tyniec-Bruges [1959], s. 881.

Tamże, s. 901. 
na jej zakorzenienie trynitarne, a następnie na trynitarną perspektywę jej urzeczywistnienia w praktyce eklezjalnej. Przedstawimy więc w tym miejscu panoramę najważniejszych typów takich modlitw zaczerpniętych z liturgii eucharystycznej Kościołów wschodnich i zachodnich. Nie zajmujemy się w tym miejscu interpretacją ewolucji, jaką przeszła doktryna trynitarna w Nowym Testamencie, ani stopniowego krystalizowania się formuł doktrynalnych w pismach nowotestamentowych. Przypomnimy na początku jedynie niektóre nowotestamentowe treści trynitarne, które znalazły bezpośrednie odzwierciedlenie w modlitwach eucharystycznych, wpływając także na ich strukturę modlitewną. Nie uwzględniamy ponadto problematyki związanej $\mathrm{z}$ formowaniem się doktryny trynitarnej w pierwszych wiekach, łącznie z wypowiedziami I Soboru Nicejskiego i I Soboru Konstantynopolitańskiego (IV wiek), w których orzeczeniach doktrynalnych teologia osiągnęła wyjątkowo znaczące poznanie objawienia Bożego na ten temat ${ }^{8}$. Opieramy się na powszechnym przekonaniu, że stosunkowo późne sformułowanie doktrynalne tych treści nie zmienia podstawowej świadomości Kościoła odnośnie do wiary trynitarnej, która w formie pośredniej była obecna i przeżywana w Kościele od samego początku. Kolejne wyjaśnienia doktrynalne pozostają zawsze zakorzenione w słowie objawionym zawartym w Piśmie Świętym i w Tradycji kościelnej, szczególnie w liturgii, będącej uprzywilejowanym nośnikiem wiary w Kościele? Pozostaje, oczywiście, prawdą, że święty depozyt utrwalony w dogmatach staje się następnie także pewną normą dla poprawnego rozumienia samego Pisma Świętego oraz światłem oświecającym poszukiwania teologiczne prowadzone ze względu na lepsze rozumienie wiary i jej pełniejsze przeżywanie ${ }^{10}$.

\section{Pierwotne formuły trynitarne w Nowym Testamencie}

Nowy Testament poucza nas o wierze w Trójcę, ale weryfikuje się to w sposób stosunkowo prosty, w jaki sam Jezus Chrystus przekazuje nam orędzie Ojca, w którym pozwala nam coraz bardziej wnikliwie poznać swoją relację z Nim, aż dochodzi do zdumiewającego stwierdzenia: „Ja i Ojciec jedno jesteśmy” (J 10, 30). W taki sam sposób mówi On także o Duchu Świętym. W Ewangelii św. Mateusza sam Pan zmartwychwstały wskazuje łącznie na trzy osoby Boże, gdy daje apostołom jednoznaczny nakaz udzielania chrztu „w imię Ojca i Syna, i Ducha

\footnotetext{
8 Por. J. Królikowski, Tajemnica Trójjedynego..., dz. cyt., s. 157-183.

9 Por. II Sobór Watykański, konst. Dei Verbum, 8.

10 Por. Katechizm Kościoła katolickiego, Poznań 2002, nr 89.
} 
Świętego" (Mt 28, 19). Podobne formuły trynitarne, przechodząc ewidentnie przez proces precyzowania doktrynalnego, znajdujemy na przykład w Drugim Liście do Koryntian $(13,13)$. Nie należy zapominać o ważnej formule, zwanej "Comma Ioanneum", która choć nie jest oryginalna, w bardzo wielu przypadkach, łącznie z epoką nowożytną, odegrała ważną rolę w doktrynalnym formowaniu się i krystalizowaniu autentycznej doktryny trynitarnej (por. $1 \mathrm{~J} 5,7)^{11}$.

Jeśli mamy na względzie taki początek orędzia chrześcijańskiego, to nie dziwi nas również fakt, że - na ile znamy modlitwę pierwszych chrześcijan - zwracają się oni w niej do Boga jako Ojca. W punkcie wyjścia tak jest ukierunkowana pierwotna modlitwa chrześcijańska i takie jest kryterium jej praktykowania $^{12}$. To prawda, że Jezus jest Panem (por. 1 Kor 12, 3), że w Jego imię udziela się chrztu, że uczniowie uważają się za sługi Chrystusa i pragną żyć „,W Jezusie Chrystusie”. W niektórych miejscach znajdujemy także ślady modlitwy, w której ma miejsce bezpośrednie zwrócenie się do Jezusa Chrystusa, na przykład św. Szczepan modli się do Niego: „Panie Jezu, przyjmij ducha mego" (Dz 7, 69). Mimo to, jak zauważył Josef A. Jungmann: „Modlitwa, która kierowała się do Chrystusa, była raczej jednak wyjątkiem, jak zdaje się wynikać również z prywatnych modlitw chrześcijanina. W każdym razie, tak było u św. Pawła” ${ }^{\prime 3}$. Modlitwa, którą chrześcijanin kieruje do Ojca, „nabiera mocy tylko wówczas, gdy jest czyniona w imię Jezusa, to znaczy Chrystusa, i gdy dosięga Boga za pośrednictwem Chrystusa"14.

W ramach tych ogólnych założeń teologicznych, wynikających wyraźnie z Nowego Testamentu, wykształciła się następnie modlitwa chrześcijańska i wyraziła w pierwszych formułach, które mają ściśle trynitarne treści i odniesienia ${ }^{15}$. Święty Justyn męczennik przekazuje, że ten, kto przewodniczy celebracji eucharystycznej, podnosząc chleb i wino, „chwali i uwielbia Ojca wszechrzeczy przez imię Syna i Ducha Świętego" ${ }^{\text {"16 }}$. Orygenes zna już klasyczną

${ }^{11}$ Por. G. McDonald, Biblical criticism in Early Modern Europe. Erasmus, the Johannine Comma, and Trinitarian debate, Cambridge 2016.

12 Por. J. Galot, Fêter le Père, Paris 1993, s. 13-43.

${ }_{13}$ J. A. Jungmann, Die Stellung Christi im liturgischen Gebet, Münster in Westf. 1962, s. 116. Praca Jungmanna wciąż pozostaje najważniejszym studium zagadnienia chrystologii modlitwy liturgicznej, a jego konkluzje są powszechnie przyjmowane.

${ }_{14}$ Tamże, s. 122.

15 Konkretne przykłady starożytnych modlitw można znaleźć w: A.-G. Hamman, Prières des premiers chrétiens, Paris 1952.

${ }^{16}$ Justyn, 1 Apologia [65,3], w: Pierwsi apologeci greccy. Kwadratus, Arystydes $z$ Aten, Aryston $z$ Pelli, Justyn Męczennik, Tacjan Syryjczyk, Milcjades, Apolinary z Hierapolis, Teofil z Antiochii, 
formułę doksologiczną, kończącą modlitwę, w której należy „wielbić Boga przez Chrystusa, który razem z Nim jest uwielbiany, w Duchu Świętym razem z Nim wychwalonym ${ }^{\prime 17}$. W IV wieku ta formuła była już w powszechnym użyciu na całym chrześcijańskim Wschodzie. Obok tej formuły znajduje się także inne sformułowanie, które jest charakterystyczne dla Hipolita: „Ut te glorificetur etlaudent per filium tuum Iesum Christum, per quem tibi gloria et honor in sancta Ecclesia nunc et semper et in saecula saeculorum"18.

Za zwieńczenie rozwoju teologii modlitwy w pierwotnym Kościele można uznać kanon 21 synodu w Hipponie z 393 roku, w którym dokonano niejako podsumowania wcześniejszej tradycji i utrwalenia w liturgii rzymskiej jej kluczowego znaczenia: „Ut nemo in precibus vel Patrem pro Filio vel Filium pro Patre nominet. Et cum altari assistitur sempre ad Patrem dirigatur oratio"'19. W tym kanonie znalazły się skodyfikowane wczesnochrześcijańskie doświadczenia dotyczące teologii modlitwy liturgicznej. Nawet jeśli w praktyce ta zasada nie zawsze była i jest $\mathrm{w}$ pełni i rygorystycznie stosowana, pozostaje stałym punktem odniesienia dla liturgicznej modlitwy Kościoła, zachowując swoje znaczenie także w prywatnej modlitwie chrześcijańskiej ${ }^{20}$.

\section{Formuły trynitarne w anaforach wielkich liturgii wschodnich}

W pojawiających się w III wieku kontrowersjach dotyczących prawowiernej interpretacji wiary w Trójcę Świętą również utrwalona już doksologia stała się przedmiotem kontrowersji i wykorzystywano ją w dysputach teologicznych. Arianie w swojej interpretacji formuły: „Chwała Ojcu przez Syna w Duchu Świętym", dopuszczali się nadużyć, starając się wykorzystać ją dla uzasadnienia swojej doktryny, według której Syn i Duch są podporządkowani Ojcu. Obrońcy prawdziwej wiary, ze św. Bazylim Wielkim na czele, pod naciskiem

Hermiasz, przeł., wstęp i komentarze L. Misiarczyk, Kraków 2004, s. 255.

17 Orygenes, O modlitwie [33], przeł. W. Kania, H. Pietras, [w:] Odpowiedź na słowo, wstęp i oprac. H. Pietras, Kraków 1993, s. 237.

18 Hipolit, Traditio Apostolica 4: Sch 11, 52.

19 Por. Concilia Africae A. 345 - A. 525: CCL 149, 39, 120-124. Por. B. Neunheuser, „Cum altari adsistitur semper ad Patrem dirigatur oratio". Der canon 21 des Konzils von Hippo 393. Seine Bedeutung und Nachwirkung, „Augustinianum” 25 (1985), s. 105-119.

${ }_{20}$ Por. Teresa od Jezusa, Droga doskonałości [1, 27], [w:] taż, Dzieła, t. 2, przeł. H. P. Kossowski, Kraków 1987, s. 130-133; H. U. von Balthasar, Modlitwa i kontemplacja, przeł. Z. Włodkowa, Kraków 1965, s. 28-39. 
tej kontrowersji zmodyfikowali więc tradycyjną doksologię, wprowadzając nową, która z niewielkimi modyfikacjami, zwłaszcza na Wschodzie, przetrwała do naszych czasów: „Chwała Ojcu z Synem i z Duchem Świętym”. Obydwie formuły doksologiczne były stosowane równolegle, przy czym wprowadzenie nowej formuły wywołało liczne sprzeciwy. Dla ich uspokojenia św. Bazyli Wielki napisał pierwszy traktat pneumatologiczny O Duchu Świętym, w którym bronił prawomocności obydwu formuł, wyjaśniając, że stosowana formuła „z Nim” odpowiadała oddawaniu czci, a formuła „przez Niego” jest bardziej właściwa dla modlitwy dziękczynienia, czyli przede wszystkim dla Eucharystii $^{21}$. Nie ulega jednak wątpliwości, że obrona prawdziwej wiary przed herezją ariańską doprowadziła do sytuacji, w której bardziej starożytna formuła straciła swoje znaczenie i zrobiła miejsce nowej.

Rozmaite kontrowersje trynitarne przyczyniły się więc do przyjęcia formuły, która - nie negując pośrednictwa Jezusa Chrystusa i „misji” Ducha Świętego - uwypukla w punkcie wyjścia współistotność trzech osób Bożych, a więc ma charakter antyariański. Jest to formuła, która w ciągu wieków utrwaliła się jako tak zwana „mała doksologia”"2 . Sytuacja liturgii w wielości jej przejawów, mimo nacisków spowodowanych kontrowersjami doktrynalnymi, pozostaje jednak bardzo zróżnicowana, odzwierciedlając tym samym wielkość i niewymowność tajemnicy Trójcy Świętej. Pokażemy tutaj podstawowe typy różnych rodzin liturgicznych, które uformowały się stopniowo zwłaszcza w IV i v wieku, odwołując się do formuł występujących w anaforach, czyli wschodnich modlitwach eucharystycznych ${ }^{23}$.

a) w Kościele aleksandryjskim

W anaforze św. Marka na początku dziękczynienia stwierdza się: „Omnia fecisti per [...] Filium tuum [...] Iesum Christum, per quem tibi, cum ipso et Spiritu Sancto gratias agentes, offerimus [...] oblationem hanc" ${ }^{24}$. A w dok-

${ }_{21}$ Bazyli Wielki, O Duchu Świętym [7, 16], przeł. A. Brzóstkowska, Warszawa 1999, s. 102-103.

${ }_{22}$ Por. B. Nadolski, Leksykon liturgii, Poznań 2006, s. 331.

${ }_{23}$ W niniejszym opracowaniu korzystamy ze zbioru modlitw eucharystycznych zebranych w: Prex eucharistica. Textus e variis liturgiis antiquioribus selecti, eds. A. Hänggi, I. Pahl, Fribourg 1968 [dalej: Prex eucharistica]. Tłumaczenia polskie wschodnich anafor eucharystycznych podajemy według: Wieczerza mistyczna. Anafory eucharystyczne chrześcijańskiego Wschodu, wybór, wstęp, przeł. i przypisy H. Paprocki, Warszawa 1988 [dalej: Wieczerza mistyczna]. Jako ogólne wprowadzenie do liturgii wschodnich por. I.-H. Dalmais, Les Liturgies d'Orient, Paris 1981.

${ }^{24}$ Prex eucharistica, s. 103; Wieczerza mistyczna, s. 74: „Wszystko stworzyłeś przez [...] Jezusa Chrystusa, przez którego Tobie, z Nim i Duchem Świętym składamy dziękczynienie, ofiarując Tobie tę duchową i bezkrwawą ofiarę". 
sologii końcowej: „Ut glorificetur [...] nomen tuum cum Iesu Christo et Sancto Spiritu. Sicut erat, et est" ${ }^{25}$. W starszym fragmencie anafory z Dêr-Balyzeh, w doksologii końcowej znajduje się następujące stwierdzenie: „Per Dominum nostrum Iesum Christum, cum quo tibi Patri gloria cum Sancto Spiritu in saecula. Amen"26.

b) w Kościołach antiocheńskich

Doksologia końcowa anafory Testamentum Domini Nostri Iesu Christi mówi: „Da deinde, Deus [...] ut tribuat tibi semper doxologiam et Filio tuo dilecto Iesu Christo, per quem tibi gloria et imperium cum Spiritu tuo Sancto in saecula saculorum. Amen"27.

c) w Kościele bizantyńskim

Na początku anafory św. Jana Chryzostoma stwierdza się: „Pro his omnibus agimus tibi gratias et unigenito Filio tuo, et Spiritui tuo sancto"28; natomiast w doksologii końcowej: „Et tribue nobis uno ore [...] laudare [...] nomen tuum, Patris et Filii, et sancti Spiritus, nunc et semper"29.

d) w Kościele syro-antiocheńskim

Anafora Dwunastu Apostołów zaczyna się od błogosławieństwa zaczerpniętego z Drugiego Listu do Koryntian: „Miłość Boga Ojca, łaska Syna Jednorodzonego, wielkiego Pana Boga i Zbawiciela naszego Jezusa Chrystusa

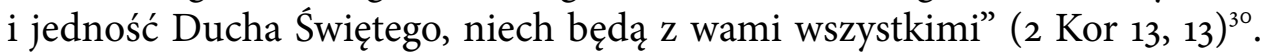
Dziękczynienie zaczyna się następująco: „Dignum et iustum est nos te adorare et te glorificare, qui vere es Deus, et unigenitum Filium tuum et Spiritum sanctum. [...] Propter haec omnia gratias agimus tibi unigenito Filio tuo et Spiritui

${ }_{25}$ Prex eucharistica, s. 115; Wieczerza mistyczna, s. 82: „Aby Twoje [...] imię było tutaj, a także na każdym miejscu wielbione, wysławiane i uświęcane wraz z Jezusem Chrystusem i Duchem Świętym".

${ }^{26}$ Prex eucharistica, s. 127; Wieczerza mistyczna, s. 84: „Przez Pana naszego Jezusa Chrystusa, z którym Tobie Ojcze Chwała z Duchem Świętym na wieki. Amen”. Podobna formuła występuje $\mathrm{w}$ anaforze Euchologionu Serapiona $\mathrm{z}$ Thmuis - por. Prex eucharistica, s. 113; Wieczerza mistyczna, s. 87 .

27 Prex eucharistica, s. 127; Wieczerza mistyczna, s. 154: „Spraw też, Panie [...] aby zawsze oddawali Tobie uwielbienie i Twemu Synowi umiłowanemu Jezusowi Chrystusowi, przez którego Tobie chwała i panowanie z Twoim Duchem Świętym, na wieki wieków. Amen”.

${ }_{28}$ Prex eucharistica, s. 225; Wieczerza mistyczna, s. 126: „Za to wszystko dzięki składamy Tobie i Jednorodzonemu Twemu Synowi i Duchowi Twemu Świętemu”.

29 Prex eucharistica, s. 229; Wieczerza mistyczna, s. 129: „I pozwól nam jednymi ustani [...] chwalić [...] imię Twoje, Ojca i Syna, i Ducha Świętego, teraz i zawsze”.

3o Wieczerza mistyczna, s. 154. 
sancto” ${ }^{31}$. W Post Sanctus kapłan mówi: „Sanctus es tu et sanctissimus, et unigenitus Filius tuus et Spiritus sanctus. Sanctus es tu [...] qui ita dilexisti mundum ut Filium tuum unigenitum dares pro illo” ${ }^{32}$, a w doksologii końcowej: „Ut etiam in hoc sicut in omnibus multum glorificetur nomen tuum benedictum cum [nomine] Iesu Christi et Spiritus tui sancti" ${ }^{33}$.

a) w Kościołach syro-orientalnych

Anafora Apostołów Addaja i Mariego, która - chociaż znamy ją na podstawie późniejszych przekazów - stanowi sięgające głębokiej starożytności świadectwo i z tej racji jest szczególnie interesująca ${ }^{34}$, w taki sposób rozpoczyna dziękczynienie: „Dignum est laude ab omni ore et confessione ab omnibus linguis [...] nomen adorandum et ladandum [Trinitatis gloriosae], Patris et Filii et Spiritus sancti, qui creavit mundum"35. Po Sanctus zostaje wspomniana świętość wszystkich osób Bożych. Doksologia końcowa nie odnosi się do poszczególnych osób, ale mówi tylko o uwielbieniu imienia Boga, to znaczy Ojca ${ }^{36}$.

Anafora Teodora z Mopsuestii wymienia poszczególne osoby Boże i szerzej do nich się odnosi ${ }^{37}$. We wprowadzeniu do Sanctus stwierdza się: „Et coram te, Pater vere, et coram Filio tuo [...] et coram Spiritu sancto consistunt millena millia sublimium spiritum. [...] Dignum etiam fecisti, Domine [...] genus nostrum infirmum [...] ut cum coetibus omnibus sublimium [...] honorem

${ }^{31}$ Prex eucharistica, s. 266; Wieczerza mistyczna, s. 154-155: „Godną i sprawiedliwą jest rzeczą, abyśmy Ciebie wielbili, Ciebie wysławiali, prawdziwego Boga Ojca, Jednorodzonego Twego Syna i Świętego Ducha. [...] Za to dzięki składamy Tobie i Twemu Jednorodzonemu Synowi i Duchowi Świętemu".

32 Prexeucharistica, s. 266; Wieczerza mistyczna, s. 155: „Święty jesteś i Najświętszy z Jednorodzonym Synem Twoim i Duchem Świętym. Święty jesteś. [...] Ty tak umiłowałeś świat, że Syna Twego Jednorodzonego dałeś".

33 Prex eucharistica, s. 268; Wieczerza mistyczna, s. 158: „Aby w tym, jak i we wszystkim, było błogosławione Twoje imię wraz z imieniem Jezusa Chrystusa i Świętego Ducha Twego".

${ }_{34}$ Por. C. Giraudo, Eucaristia per la Chiesa. Prospettive teologiche sulleucaristia a partire dalla "lex orandi”, Roma-Brescia 1989, s. 455-464.

35 Prex eucharistica, s. 376; Wieczerza mistyczna, s. 278: „Godne chwały wszystkich ust i wyznawania przez wszystkie języki [...] jest [...] chwalebne imię [Trójcy], Ojca i Syna, i Ducha Świętego. On stworzył świat”.

36 Por. Prex eucharistica, s. 380; Wieczerza mistyczna, s. 282: „Odpowiadając śpiewem, chwałą, wyznaniem i uwielbieniem Twego imienia żywego, świętego i ożywiającego, teraz i zawsze, i na wieki wieków".

37 Por. Prex eucharistica, s. 375-380; Wieczerza mistyczna, s. 282-291. 
referrent $[\ldots]$ ad celebrandum gloriam Trinitatis tuae gloriosae, quae in tribus personis aequalibus et non separatis proclamatur" ${ }^{38}$.

Przytoczone teksty liturgiczne odznaczają się znaczącą różnorodnością treściową, chociaż trzeba zarazem zauważyć, że wszystkie one są jasnym świadectwem jednoznacznego ukierunkowania trynitarnego liturgii wschodniej. Za Jungmannem można wyróżnić trzy typy tego ukierunkowania. Pierwszy typ, uznany przez niego za „główny typ grecki”, za punkt odniesienia przyjmuje porządek osób ściśle złączony z dziejowym urzeczywistnianiem się ekonomii zbawienia. Chodzi w tym przypadku o formuły, które zwracają się do Ojca, by uwielbiać Go „z Synem i z Duchem Świętym”. Drugi typ, uznany przez Jungmanna za „główny typ syryjski”, zwraca się równocześnie i bezpośrednio do trzech osób Bożych: „Gratias tibi et Filio et Spiritui” albo „coram te, Pater, et coram Filio tuo, et coram Spiritu”. Trzeci typ, używany rzadko i obecny dopiero w późniejszych formułach, mówi już o Trójcy: „ad celebrandam Trinitatis tuae"39.

Ta różnorodność odznacza się więc pewną swobodą i na początku nie odwołuje się jeszcze do jakichś ścisłych reguł, które byłyby uznane za kryterium ortodoksji. Różne liturgie w sposób dowolny odwołują się do zróżnicowanych formuł i z nich korzystają. $Z$ biegiem czasu sytuacja ulegała jednak stopniowo zmianie, co widać zwłaszcza w zmieniającym się w tych formułach miejscu zajmowanym przez Jezusa Chrystusa. Jungmann trafnie zauważył: „Jest wspólny całemu W schodowi fakt, że stopniowo schodzi na drugie miejsce, osłabia się, a w końcu znika wykorzystanie tych tekstów, które przedstawiają Chrystusa jako pośrednika, zwłaszcza pośrednika modlitwy. Przeciwnie, coraz bardziej centralnego znaczenia, jako przedmiot adoracji, nabiera majestat trójosobowego Boga - Ojca, Syna i Ducha Świętego - któremu jest oddawana cześć w każdej modlitwie" ${ }^{40}$.

${ }_{38}$ Prex eucharistica, s. 382; Wieczerza mistyczna, s. 283-284: „Przed Tobą, o Boże, Ojcze prawdziwy, przed Synem Twoim Jednorodzonym [...] i przed Duchem Świętym stoją tysiące tysięcy duchów niebieskich, miriady świętych Aniołów. [...] Przez łaskę swoją, Panie, sprawiłeś, że nasz słaby rodzaj [...] stał się godny, aby [...] oddawał cześć [...] dla wypełnienia chwały Twojej chwalebnej Trójcy, która jest wyznawana w trzech osobach, równych i nierozdzielnych".

39 Por. J. A. Jungmann, Die Stellung Christi..., dz. cyt., s. 169-177.

40 Tamże, s. 177. 


\section{Formuły trynitarne}

\section{w liturgiach zachodnich}

Całkowicie inaczej wygląda sytuacja w liturgii rzymskiej, na której skoncentrujemy się w naszych analizach, biorąc pod uwagę jej starożytność oraz rozpowszechnienie. Uwzględnimy częściowo także liturgię gallikańską, pomijamy natomiast inne liturgie zachodnie, ponieważ pozostawały one w cieniu liturgii rzymskiej i w odniesieniu do niej się kształtowały (np. liturgia amrozjańska czy rawennateńska).

Sięgnijmy więc do najstarszych elementów liturgii rzymskiej, by potem móc we właściwym świetle patrzeć na liturgię współczesną zawartą w Mszale rzymskim: w modlitwie eucharystycznej (kanonie), prefacji, a następnie w modlitwach odmawianych przez kapłana. Przede wszystkim, co zawsze podkreślano, liturgia rzymska odznacza się prostotą języka, w sposób zwarty wyrażającego treść wiary, nie pomniejszając przy tym jej poprawności dogmatycznej. W liturgii rzymskiej mamy, właściwie biorąc, jedną doksologię ${ }^{41}$ - przywołaną na początku tego studium - która odznacza się nadzwyczajną wzniosłością; zwieńcza ona starożytny „kanon rzymski”, który otwarty przez prefację zwraca się do Ojca przez Chrystusa w Duchu Świętym. Kościół rzymski w swoim kanonie, wyrażonym w uroczystym języku łacińskim pochodzącym z późnej epoki patrystycznej, zachował wyraźnie styl, którym starożytny Kościół (także Kościół wschodni) wypowiadał tajemnicę Trójcy Świętej. Rzym zachował ten język z największą wiernością, która, uwzględniając także pojawiające się kontrowersje doktrynalne, była znakiem czci wobec pierwotnych formuł liturgicznych i ich znaczenia teologicznego.

To, co w kanonie rzymskim zostaje wyrażone w formie uroczystej, zwracając się do Ojca przez Chrystusa w Duchu Świętym (to znaczy „w jedności z Duchem Świętym"42), w sposób skromniejszy jest obecne we wszystkich modlitwach, które zawsze zwracają się do Ojca przez Chrystusa, naszego Pana, czyli odwołując się do Jego pośrednictwa, który jako Bóg z Ojcem i z Duchem Świętym żyje i króluje na wieki wieków. Najstarsze sakramentarze nie znają wyjątku od tej reguły. Wyjątki zaczynają pojawiać się dopiero w Sakramentarzu gregoriańskim. Od viı/viı wieku wraz ze starożytnymi formami modlitw

${ }^{41}$ Gloria in excelsis, tak zwana „wielka doksologia”, która jest śpiewana wspólnie, oraz Gloria Patri..., czyli tak zwana „mała doksologia”, która kończy Psalmy, mają inny charakter.

${ }^{42}$ Por. J. A. Jungmann, Die Stellung Christi..., dz. cyt., s. 181. 
pojawiają się także inne formuły, które wyrażają nowy sposób zwracania się do Trójcy. Wspomnimy je w dalszej części.

Także w całej „liturgii galijskiej”, a nawet w „liturgii gallikańskiej” w sensie ścisłym, podobnie jak w liturgii rzymskiej, modlitwy najczęściej zwracają się do Ojca przez Chrystusa, aby uwielbić Go w jedności Ducha Świętego („in unitate Spiritus Sancti”). Niekiedy już w tekstach starożytnych zdarzają się jednak wyjątki od tej reguły. W komentarzu do antologii Prex eucharistica, z której tutaj korzystamy, autorzy Anton Hänggi i Irmgard Pahl zauważają odnośnie do „liturgii gallikańsko-celtyckiej”, że nie zwiera ona ewidentnych norm dotyczących modlitw liturgicznych, o czym świadczy fakt, że raz zwracają się one do Ojca, a innym razem do Chrystusa ${ }^{43}$. Podobna sytuacja zachodzi w liturgii hiszpańskiej, która nie tylko nie stosuje się do jednej zasady, ale posiada także bardzo rozbudowaną chrystologię liturgiczną ${ }^{44}$. Nie kładąc szczególnego akcentu na charakter trynitarny ukierunkowania modlitwy i prezentując większą dowolność w tym względzie, liturgia hiszpańska, na przykład w licznych modlitwach Post pridie, zwraca się do Ojca, aby On, mając wzgląd na odkupieńcze dzieło Syna, zechciał posłać Ducha Świętego na złożone dary ${ }^{45}$. Spotykamy w tej liturgii, w Post pridie, także formułę skierowaną do Chrystusa: „Ut eodem Spiritu, quo in te carne virginitas incorrupta concepit, has hostias Trinitas indivisa sanctificet" 4 .

To samo można powiedzieć o Mszach z Mone $^{47}$ i o Missale Gothicum te teksty mogą być uważane za relatywnie pewne świadectwo czystej liturgii gallikańskiej ${ }^{4}$. Piąta Msza z Mone posiada we „wprowadzeniu” następującą modlitwę: „Omnipotentem Deum in Trinitate venerabili subsistentem, Patrem [...] Filium cum Patre semper extantem [...] depraecemur" "49, a w contestatio (odpowiednik rzymskiej prefacji): „Dignum et iustum est [...] tibi gratias agere, omnipotens aeterne Deus, Pater, Unigenite, Spiritus Sancte. [...] Una eademque in sanctam Trinitatem trium personarum substantiam, coaeterna

43 Por. Prex eucharistica, s. 461.

${ }_{44}$ Por. tamże, s. 495. Szeroki wykład problematyki chrystologicznej w liturgii hiszpańskiej można znaleźć w: P. Roszak, Mozarabowie i ich liturgia. Chrystologia rytu hiszpańsko-mozarabskiego, Toruń 2015.

45 Por. Prex Eucharistica, s. 500, 507.

46 Tamże, s. 504.

47 Por. Missale Gallicanum vetus, a cura di L. C. Mohlberg, L. Eizenhöfer, P. Siffrin, Roma 1958.

${ }^{48}$ Por. Missale Gothicum, a cura di L. C. Mohlberg, Roma 1961. Por. także J. A. Jungmann, Die Stellung Christi..., dz. cyt., s. 82.

49 Missale Gallicanum vetus, dz. cyt., nr 313. 
essentia et non discreta concordia” ${ }^{50}$. Inna contestatio mówi: „Dignum et iustum est [...] gratias agere, Trinitas Deus, cuius nos potestas verbo creavit" 51 .

Mimo tych przykładów nie można stwierdzić - odnosi się to szczególnie do Missale Gothicum - że modlitwa kierowana do Trójcy Świętej zyskała jakieś pierwszeństwo w liturgii. Jest ona obecna i jest dowolnie wykorzystywana, mimo obowiązywania zasady, że modlitwy liturgiczne mają zawsze kierować się do Ojca. W pełni odpowiada to zresztą zasadniczej strukturze trynitarnej nadanej egzystencji chrześcijańskiej za pośrednictwem chrzcielnego wyznania wiary. Dlatego jest między innymi powiedziane w formule infra actionem mszy in monasterio w Sakramentarzu gelazjańskim: „Hanc igitur oblationem [...] suscipias [...] et semper in tua religione laetantes instanter in Sanctae Trinitatis fide catholica perseverent" ${ }^{2}$.

Modlitwy tego rodzaju, których genezy trzeba szukać w środowisku gallikańskim, zaczynają około vıı wieku być wprowadzane do liturgii rzymskiej. Dzieje się to na mocy ogólnego przenikania się liturgii franko-gallikańskiej i liturgii rzymskiej, w której była dotychczas w modlitwach mszalnych używana wyłącznie najstarsza i najbardziej pierwotna formuła, to znaczy kierowana do Ojca przez Jezusa Chrystusa w Duchu Świętym. Jako świadectwa tego przenikania można tutaj wskazać: wezwania skierowane do Trójcy Świętej pochodzące z VIII wieku ${ }^{53}$, mszę o Trójcy Świętej, której początki sięgają 800 roku i będącej w użyciu do dzisiaj ${ }^{54}$, a przede wszystkim od IX wieku modlitwy należące do Ordo Missae, jak na przykład: „Suscipe sancta Trinitas”. Należy do tego samego procesu fakt, że nowe Kyrie mszy także podlegają modyfikacjom, nabierając znaczenia trynitarnego, to znaczy stając się wezwaniami Trójcy Świętej ${ }^{56}$. Mimo wprowadzania wspomnianych modyfikacji liturgia jako całość pozostaje wierna swoim tradycyjnym formom.

Mówiąc o rozwoju trynitarnych wątków w liturgii eucharystycznej, nie należy oczywiście zapominać, że wyznanie Trójcy Świętej ma od początku wyjątkowe

50 Tamże, nr 317.

${ }_{51}$ Tamże, nr 328; por. także nr 281.

52 Sacramentarium Gelasianum, a cura di L. C. Mohlberg, Roma 1960, nr 1434.

53 Por. Sacramentarium Gelasianum vetus, dz. cyt., nr 680.

54 Por. Sacramentarium Fuldense saeculi X, eds. G. Richter, A. Schönfelder, Fulda 1912, nr 1009-1012.

5 Por. B. Luykx, Der Ursprung der gleichbleibenden Teile der heiligen Messe, „Liturgie und Mönchtum" 29 (1961), s. 72-119.

${ }_{56}$ Por. M. Metzger, Storia della celebrazione eucaristica in Occidente, [w:] Scientia liturgica. Manuale di Liturgia, vol. 3: L'Eucaristia, direzione di A. J. Chupungo, Casale Monferrato 1998, s. 127. 
znaczenie w celebracji chrztu, który zawsze jest udzielany „w imię Ojca i Syna, i Ducha Świętego", nawet jeśli pojawiają się jakieś modyfikacje w samym obrzędzie jego udzielania. Również w celebrowaniu innych sakramentów formuła „W imię Ojca i Syna, i Ducha Świętego” posiada pierwszorzędne znaczenie.

Cały Psałterz jest przeniknięty doksologią Gloria Patri et Filio et Spiritui Sancto. Od czasów starożytnych śpiewa się w liturgii mszalnej „wielką doksologię" Gloria in excelsis Deo, bedącą najbardziej klasycznym uwielbieniem trzech osób Bożych. W Officium Divinum uwielbienie Trójcy Świętej szczególnie rozbrzmiewa w doksologiach kończących hymny. Święty Ambroży z Mediolanu jeszcze ich nie zna, albo zna tylko w formie uproszczonej, jak można wnioskować choćby z następującego przykładu:

Aurora cursus provehit,

Aurora totus prodeat,

In Patre totus Filius

Et totus in Verbo Pater ${ }^{57}$.

Później doksologie trynitarne stały się powszechne, chociaż trzeba powiedzieć, że Kościół rzymski był bardzo ostrożny w przyjmowaniu hymnów ${ }^{58}$.

Ważny ponadto jest fakt, że Ordo Missae, uformowane od Ix wieku, umieszcza na początku modlitw kapłana formułę przejętą z liturgii chrzcielnej: „In nomine Patris et Filii et Spiritus Sancti”. Stała się ona w ciągu wieków najbardziej rozpowszechnioną modlitwą, a zarazem archetypem modlitwy chrześcijańskiej, wyznaniem wiary i manifestacją tożsamości chrześcijańskiej. Wyjaśnia się w tym przypadku, w jaki sposób bardzo ważna modlitwa, nawet jeśli z liturgicznego punktu widzenia jest tylko marginalna, z biegiem czasu może zostać pogłębiona i nabrać zupełnie nowego znaczenia. Dokonywanie się takiego samego procesu widać w rozmaitych modlitwach, zarówno liturgicznych, jak i prywatnych, na przykład zostawionych przez świętych i mistyków. Zasługuje na zauważenie zachodzenie tego procesu w reformie liturgicznej, którą zapoczątkował II sobór watykański, a której rezultatem jest nadanie nowym obrzędom celebracji sakramentów wyraźniejszego charakteru trynitarnego ${ }^{59}$.

57 Hymni instaurandi Breviarii Romani, a cura di A. Lentini, Città del Vaticano 1968, s. 30.

${ }_{58}$ Por. M. Righetti, Manuale di storia liturgica, vol. 2: L’anno liturgico. Il breviario, Milano 1955, s. 585 .

59 Por. Ch. Morerod, The Trinity, the Church, and the Sacraments, [w:] The Oxford handbook of the Trinity, eds. G. Emery, M. Levering, Oxford 2011, s. 428-441. 
Niejako dopełnia się w ten sposób wędrówka życia chrześcijańskiego, którą liturgia sytuuje w wyraźnej perspektywie trynitarnej, nawet jeśli sformułowania teologiczne tej perspektywy nie zawsze są ewidentnie widoczne w samych formułach modlitewnych, w których literalne odniesienie do Trójcy Świętej jako takiej pojawia się stosunkowo rzadko. Liturgia zachodnia, w tym przede wszystkim rzymska, stawia na pierwszym miejscu modlitwę wierną starożytnemu ukierunkowaniu, które odzwierciedla porządek zbawienia: do Ojca przez Chrystusa w Duchu Świętym. Nawet jeśli odniesienie pojęciowe do Trójcy Świętej nie jest w tym przypadku całkiem wyraźne, to jednak sama tajemnica Trójcy Świętej w jej wymiarze ekonomicznym (ad extra) jest ponad wszelką wątpliwość stawiana na pierwszym miejscu. W tej sytuacji jest zrozumiałe, że osobne „święto Trójcy Przenajświętszej”, chociaż ma starożytną genezę i zostało szeroko przyjęte, pozostaje w pewnym sensie obce tradycyjnie rozumianej liturgii Kościoła.

\section{Święto Trójcy Przenajświętszej}

Początki Święta Trójcy Przenajświętszej ściśle łączą się z utrwaleniem się prefacji i odpowiedniego formularza mszalnego ${ }^{60}$. Prefacja i formularz mszalny oraz jego ewolucja zasługiwałyby na osobne potraktowanie, aby wydobyć ich teologię oraz określić jej specyfikę. Zagadnienie to jednak wykracza poza ramy niniejszego studium, dlatego powrócimy do niego w osobnym opracowaniu. W tym miejscu chcemy tylko pokazać stopniowy wpływ wywierany przez modlitwę kierowaną do Trójcy Świętej na uformowanie się dedykowanego Jej święta.

Msza według formularza poświęconego Trójcy Świętej była często celebrowana w średniowieczu. Niektóre reguły monastyczne przepisywały ją jako pierwszą mszę (missa matutinalis) na wszystkie niedziele, które nie pokrywały się z innymi świętami, przynajmniej w okresie od Zesłania Ducha Świętego do Adwentu. Nie oznacza to, że było już przyjęte jakieś osobne święto. Propagowana pobożność, mająca za przedmiot Trójcę Przenajświętszą, zmierzała jednak stopniowo do nadania jej konkretnej i skodyfikowanej formy liturgicznej i do poświęcenia jej wybranej niedzieli.

Mnisi z Cluny mieli w swoim kalendarzu festum de Trinitate w oktawie Pięćdziesiątnicy, od których przejęły je inne klasztory św. Benedykta. Cystersi

${ }^{60}$ Por. A. Klaus, Ursprung und Verbreitung der Dreifaltigkeitsmesse, Werl 1938; P. Browe, Zur Geschichte der Dreifaltigkeitsfestes, „Archiv für Liturgiewissenschaft” 1 (1950), s. 65-81. 
na początku wyraźnie dystansowali się w stosunku do niego. W dyspucie autorstwa mnicha Idunga, którą każe prowadzić dwom mnichom, kluniackiemu i cysterskiemu, znajdujemy taką wypowiedź cystersa, który sprzeciwia się wprowadzaniu nowego święta poświęconego Trójcy Świętej: „Nie powinna mieć żadnego specjalnego święta, bo w psalmach, hymnach, responsoriach i oficjach mszalnych powinniśmy codziennie śpiewać ku czci i chwale Trójcy Świętej: Chwała Ojcu i Synowi, i Duchowi Świętemu" "1. Mimo początkowego oporu cystersi bardzo szybko stanęli na stanowisku prezentowanym przez mnichów z Cluny, gdyż już na końcu XıI wieku obchodzili święto Trójcy Przenajświętszej. Podobne wahania znajdujemy w wielu miejscach, zarówno w tradycjach zakonnych, jak i diecezjalnych. Zastrzeżenia odnośnie do ustanowienia osobnego święta poświęconego Trójcy Przenajświętszej sprowadzały się właściwie do dwóch: nie było ono znane w starożytności oraz - właściwie biorąc - w każdej mszy ta tajemnica jest czczona i zawsze ma to charakter uroczysty.

Mamy wyraźne świadectwa na ten temat. Bernold z S. Blasins, autor dziełka poświęconego kwestiom liturgicznym Micrologus powstałego po roku 1086, powołuje się na papieża Aleksandra II ( $† 1073)$, który miał powiedzieć: „Iuxta romanum ordinem nullum diem specialiter ascribi debere solemnitati Sanctae Trinitatis, sicut nec sanctae unitatis, praecipue cum in omni dominica, imo quotidie, utriusque memoria celebretur" ${ }^{32}$. Taki sam osąd wydał papież Aleksander III (†1181) w liście, który został włączony do Corpus Iuris Canonici: „Ecclesia siquidem romana in usu non habet, quod in aliquo tempore huiusmodi celebret specialiter festivitatem" ${ }^{63}$.Wymienieni papieże, chociaż podnosili pewne zastrzeżenia, samo święto tolerowali. W xıI wieku miało ono coraz większy zasięg; najpierw rozpowszechniło się we Francji, potem w Anglii, a w XIII wieku także w Niemczech. W Italii nie było znane jeszcze w późnym średniowieczu. Zwyczaj liczenia niedziel, biorąc za punkt wyjścia Święto Trójcy Przenajświętszej, zamiast od oktawy Pięćdziesiątnicy, pojawił się dopiero w XIV wieku. Wspólnoty reformowane zachowują ten zwyczaj do dnia dzisiejszego. Występowała też pewna różnica odnośnie do dnia, w którym to święto było celebrowane, gdyż w niektórych Kościołach we Francji i w Hiszpanii obchodzono je w ostatnią niedzielę po Pięćdziesiątnicy.

${ }^{61}$ Idung, Dysputa dwóch mnichów [1, 42], [w:] Polemika kluniacko-cysterska z XIII wieku, przeł. E. Buszewicz, red. i wstęp M. T. Gronowski, Kraków 2010, s. 378-379.

${ }_{62}$ Bernold, Micrologus de ecclesiasticis observationibus 60: PL 151, 1020.

${ }_{63}$ Decretales Gregorii IX 2, 9, 2, [w:] Corpus Iuris Canonici, vol. 2, ed. A. Friedberg, Leipzig 1879, s. 261. 
W 1334 roku Stolica Święta przestała przeciwstawiać się ustanowieniu święta, gdy papież Jan XXII określił także sposób jego celebracji, co odnotowały współczesne mu kroniki. W 1499 roku papież Aleksander vi zakazał obchodzenia niedzieli, gdy przypadało święto Trójcy Przenajświętszej. Papież św. Pius x nadał świętu rangę „obrzędu podwójnego pierwszej klasy” (ritu duplici primae (lassis) $)^{64}$.

Msza o Trójcy Przenajświętszej, która pierwotnie była mszą wotywną, po raz pierwszy znalazła się w Missale Fuldense pochodzącym z x wieku, którego autorem, albo raczej kompilatorem, być może był Alkuin ${ }^{65}$. Oficjum w swoich istotnych częściach jest związane z osobą Jana Peckhama, arcybiskupa Canterbury (†1292). Obecny kształt został mu nadany przez papieża św. Piusa v. Reforma liturgiczna przeprowadzona po II soborze watykańskim nadała Niedzieli Trójcy Przenajświętszej (Dominica de Trinitate) wysoką rangę liturgiczną „uroczystości”. W obecnym kształcie ta uroczystość potwierdza wielowiekowy rozwój tradycji liturgicznej i kultycznej, niejako koronując rok liturgiczny - w którym jest wspominane cało dzieło zbawienia, w jakim Bóg Trójca obdarował nas swoim miłosierdziem i swoją uszczęśliwiającą wspólnotą uroczystością, która jest bezpośrednim wyznaniem wiary w Boga Jedynego i Troistego, połączonym z uwielbieniem Go jako Boga żywego, najświętszego, niewymownego, jako Pana Wiecznego Majestatu. Prefacja o Trójcy Świętej może więc być uznana za ważny element uroczystości Trójcy Przenajświętszej, ale nie wyczerpuje się w niej przesłanie doktrynalne i duchowe, jakie jest zawarte w całej uroczystości i w jej obchodzeniu w roku liturgicznym. Nawet jeśli więc jej treści stanowią jakieś streszczenie doktryny Kościoła, to jednak może być ona traktowana tylko jako inspiracja i perspektywa, a nie jako zwieńczenie trynitarnego doświadczenia wiary Kościoła, jak zadaje się sugerować Paweł Beyga w swoich bardzo trafnych uwagach na temat prefacji o Trójcy Przenajświętszej zaprezentowanych na łamach „Teologii w Polsce”66 .

${ }^{64}$ Święta Kongregacja Obrzędów, Decretum (24 czerwca 1911), „Acta Apostolicae Sedis” 3 (1911), s. 351.

${ }_{65}$ Por. J. A. Jungmann, Liturgisches Erbe und pastorale Gegenwart. Studien und Vorträge, Innsbruck-Wien-München 1960, s. 47.

${ }^{66}$ Por. P. Beyga, Dogmat jako przestrzeń uwielbienia Boga w liturgii na przykładzie prefacji o Trójcy Świętej, „Teologia w Polsce” 10 (2016) nr 1, s. 177-187. 


\section{"Jedna wiara i jedna cześć"}

Podsumowując, należy przede wszystkim podkreślić, że liturgie wszystkich Kościołów Wschodu i Zachodu są konsekwentnie oparte na wyznaniu wiary w Boga Trójcę, zakorzeniając się w objawieniu, które On sam urzeczywistnił w dziejach zbawienia - Bóg Ojciec posłał swego Jednorodzonego Syna, Jezusa Chrystusa, aby odkupił człowieka przez swoją śmierć i zmartwychwstanie, to znaczy przez swoje paschalne misterium zbawienia, a następnie jako nasz Pan zasiadł po prawicy Ojca, skąd posłał swojego Ducha Parakleta, aby dokonywał uświęcającej i oświecającej przemiany ludzi w Jego Ciało, którym jest Kościół. Teraz dzieje zbawienia, mające w punkcie wyjścia ewidentną treść i strukturę trynitarną, dopełniają się w Kościele, a przez niego w poszczególnych wierzących. Na pierwszym miejscu to dopełnianie w sposób odpowiadający dziełu zbawienia urzeczywistnia się w liturgii kościelnej ${ }^{67}$. Liturgia jest więc nadzwyczajną syntezą tego wielkiego dzieła zbawienia dokonanego „raz na zawsze" i dokonywanego nieustannie przez Boga, a zarazem bramą, przez którą wierzący dochodzi do żywego uczestniczenia w jego skutkach, a tym samym w wypełnieniu swojego przeznaczenia.

W każdej tradycji liturgicznej jest obecna możliwość zwrócenia się bezpośrednio do trzech osób Bożych za pośrednictwem równoczesnego wezwania Ojca i Syna, i Ducha Świętego bądź też zwrócenia się osobno do Ojca, do Syna i do Ducha Świętego. Pierwszeństwo posiada, zakorzeniające się w nowotestamentowej tradycji modlitwy i potwierdzone w dziejach duchowości chrześcijańskiej, zwracanie się do Boga Ojca. Rzadziej spotykamy modlitwę kierującą się wprost do Trójcy Świętej, chociaż i taka modlitwa jest obecna już we wczesnym średniowieczu, przede wszystkim na Wschodzie i w liturgiach nierzymskich na Zachodzie. Liturgia rzymska spokojnie przyjęła takie formy modlitwy w wiekach IX-XI, ale pozostała wierna w swoich zasadniczych liniach formie modlitwy nawiązującej do dziejów zbawienia: do Ojca przez Chrystusa w Duchu Świętym. Po długim okresie zastrzeżeń i wątpliwości przyjęła ona także osobne święto poświęcone Trójcy Przenajświętszej, które dzisiaj należy do powszechnego dziedzictwa liturgii i pobożności w Kościele, spełniając swoją wieloraką funkcję, przede wszystkim przypominając, że tajemnica Trójcy Świętej jest tajemnicą wszystkich tajemnic chrześcijańskich oraz podstawą życia ochrzczonych. W ten sposób staje się ona szkołą życia konsekwentnie trynitarnego: „Wierzymy więc w Boga, który wiecznie rodzi

${ }^{67}$ Por. II Sobór Watykański, Konst. Sacrosanctum Concilium, 7. 
Syna; wierzymy w Syna, Słowo Boże, które wiecznie jest rodzone; wierzymy w Ducha Świętego, Osobę niestworzoną, która pochodzi od Ojca i Syna jako Ich wieczna miłość" ${ }^{68}$.

Formy pobożności trynitarnej wyrażanej w liturgii są wielorakie; są one również stosowane w sposób stosunkowo dowolny. Wszystkie jednak zachowują swoją wartość, byle zostało w nich zachowane zasadnicze ukierunkowanie teologiczne, które ma swoją genezę i swój punkt odniesienia w najstarszych początkach, które Kościół rzymski wiernie przekazuje w swojej liturgii. Niezgłębioność i niewymowność tajemnicy Trójcy Przenajświętszej domaga się od wierzących i od teologów, aby zgłębiać ją i kontemplować z jak największą otwartością duchową i intelektualną, z której może rodzić się także otwarta pobożność, pozwalająca wszędzie odkrywać ślady tej świętej tajemnicy.

\section{ABSTrAKT}

Formuły trynitarne we wschodnich i zachodnich modlitwach eucharystycznych Sakramenty chrztu i Eucharystii stanowią centrum liturgii Kościoła, gdyż są uroczystą celebracją tajemnicy wiary oraz wskazują na te treści, które stanowią kluczowy punkt odniesienia dla życia wszystkich wierzących. Fakt ten widać przede wszystkim w tym, że od samego początku istnienia Kościoła obrzędy chrztu i Eucharystii stanowią pierwsze i najważniejsze świadectwo wiary w Trójcę Świętą oraz są wyznaniem tej wiary. Ta ogólna obserwacja wyznacza perspektywę niniejszego studium, w którym pokazujemy, w jaki sposób w liturgii następowała pewna ewolucja wiary w Trójcę Świętą i jak doszło do utrwalenia tej wiary w obecnej liturgii. W niniejszym studium dokonujemy więc przeglądu formuł trynitarnych, które można znaleźć w liturgiach wschodnich i zachodnich, aby pokazać, w jaki sposób wyrażają się w nich treści trynitarne. W odniesieniu do liturgii zachodnich zwracamy szczególną uwagę na liturgię rzymską i liturgię gallikańską, które wyraźnie oddziaływały na siebie w dziejach, a obecna liturgia rzymska jest rezultatem tego oddziaływania. Pośrednim efektem rozwoju formuł trynitarnych oraz pobożności o charakterze trynitarnym jest także liturgiczne święto Trójcy Przenajświętszej, które mimo pewnych początkowych trudności zajęło na trwałe miejsce w liturgii Kościoła. Przeprowadzone analizy pokazują przede wszystkim, że liturgia Kościoła jest ważnym świadectwem wiary trynitarnej oraz szkołą jej przeżywania w kluczu soteriologicznym. Lepsze odczytanie propozycji

${ }^{68}$ Paweł vi, Wyznanie wiary Ludu Bożego - Credo Populi Dei, przeł. J. Królikowski, Kraków 2012, s. 17. 
liturgicznej mogłoby przyczynić się do ożywienia wiary trynitarnej i wydobycia jej znaczenia egzystencjalnego.

\section{SŁOWA KLUCZOWE}

Trójca Przenajświętsza, chrzest, Eucharystia, liturgia, modlitwa eucharystyczna, wyznanie wiary

\section{Abstract}

\section{Trinitarian formulas in eastern and western Eucharistic Prayers}

The Sacraments of Baptism and Eucharist constitute the centre of the Church liturgy, since they are a solemn celebration of faith and they point at those issues which constitute the key benchmark for life of all the believers. It is most clearly visible in the fact that from the very beginnings of the Church the rites of baptism and Eucharist constitute the first and most significant testimony of faith in the Holy Trinity and they are the profession of this faith. This general observation outlines the perspective of this study which shows in what way, in the liturgy, a certain evolution of faith in the Holy Trinity took place, and how this faith has been consolidated in the present day liturgy. Therefore this study is an attempt to review the Trinitarian formulas which may be found in eastern and western liturgies, in order to show in what way they express the Trinitarian contents. In reference to western liturgies we focus mainly on the Roman and Gallican liturgies which clearly interacted throughout history, and the present Roman liturgy is the outcome of this interaction. The side effect of the development of the Trinitarian formulas and the Trinitarian piety is the liturgical holiday of the Solemnity of the Most Holy Trinity which despite certain initial difficulties has found its place in the Church liturgy. The analyses carried out show, in the first place, that the Church liturgy is an important testimony of the Trinitarian faith and the example of how to experience it within the soteriological framework. Better understanding of the liturgical proposition might contribute to the revival of the Trinitarian faith and to the eliciting of its existential meaning.

\section{KEYWORDS}

Holy Trinity, baptism, Eucharist, liturgy, Eucharistic Prayer, Profession of Faith

\section{BiBLIOGRAFIA}

Balthasar H. U. von, Modlitwa i kontemplacja, przeł. Z. Włodkowa, Kraków 1965. Bazyli Wielki, O Duchu Świętym, przeł. A. Brzóstkowska, Warszawa 1999. 
Beyga P., Dogmat jako przestrzeń uwielbienia Boga w liturgii na przykładzie prefacji o Trójcy Świętej, „Teologia w Polsce” 10 (2016) nr 1, s. 177-187.

Beyga P., Recenzja, „Teologia w Polsce” 10 (2016) nr 1, s. 273-276.

Boguniowski J. W., Rozwój historyczny ksiag liturgii rzymskiej do Soboru Trydenckiego $i$ ich recepcja w Polsce, Kraków 2001.

Browe P., Zur Geschichte der Dreifaltigkeitsfestes, „Archiv für Liturgiewissenschaft” 1 (1950), s. 65-81.

Corpus Iuris Canonici, vol. 2, ed. A. Friedberg, Leipzig 1879.

Dalmais I.-H., Les Liturgies d'Orient, Paris 1981.

Galot J., Fêter le Père, Paris 1993.

Giraudo C., Eucaristia per la Chiesa. Prospettive teologiche sulleucaristia a partire dalla ,lex orandi", Roma-Brescia 1989.

Hamman A.-G., Prières des premiers chrétiens, Paris 1952.

Hymni instaurandi Breviarii Romani, a cura di A. Lentini, Città del Vaticano 1968.

Jungmann J. A., Liturgisches Erbe und pastorale Gegenwart. Studien und Vorträge, Innsbruck-Wien-München 1960.

Jungmann J. A., Die Stellung Christi im liturgischen Gebet, Münster in Westf. 1962. Jungmann J. A., Missarum solemnia. Eine genetische Erklärung der römischen Messe, Bd. 2, Wien-Freiburg-Basel 1962.

Jungmann J. A., Liturgia pierwotnego Kościoła do czasów Grzegorza Wielkiego, przeł. T. Lubowiecka, Kraków 2013.

Katechizm Kościoła katolickiego, Poznań 2002.

Klaus A., Ursprung und Verbreitung der Dreifaltigkeitsmesse, Werl 1938.

Królikowski J., Tajemnica Trójjedynego. Studia z teologii trynitarnej, Kraków 2015.

Luykx B., Der Ursprung der gleichbleibenden Teile der heiligen Messe, „Liturgie und Mönchtum" 29 (1961), s. 72-119.

McDonald G., Biblical criticism in Early Modern Europe. Erasmus, the Johannine Comma, and Trinitarian debate, Cambridge 2016.

Missale Gallicanum vetus, a cura di L. C. Mohlberg, L. Eizenhöfer, P. Siffrin, Roma 1958. Missale Gothicum, a cura di L. C. Mohlberg, Roma 1961.

Mszał rzymski z dodaniem nabożeństw nieszpornych, oprac. O. G. Lefebvre, przekład polski opracowali mnisi opactwa w Tyńcu, Tyniec-Bruges [1959].

Neunheuser B., „Cum altari adsistitur semper ad Patrem dirigatur oratio”. Der canon 21 des Konzils von Hippo 393. Seine Bedeutung und Nachwirkung, „Augustinianum” 25 (1985), s. 105-119.

Nadolski B., Leksykon liturgii, Poznań 2006.

Odpowiedź na słowo, wstęp i oprac. H. Pietras, Kraków 1993. 
Pierwsi apologeci greccy. Kwadratus, Arystydes z Aten, Aryston z Pelli, Justyn Męczennik, Tacjan Syryjczyk, Milcjades, Apolinary z Hierapolis, Teofil z Antiochii, Hermiasz, przeł., wstęp i komentarze L. Misiarczyk, Kraków 2004.

Paweł vi, Wyznanie wiary Ludu Bożego - Credo Populi Dei, przeł. J. Królikowski, Kraków 2012.

Polemika kluniacko-cysterska z XIII wieku, przeł. E. Buszewicz, red. i wstęp M. T. Gronowski, Kraków 2010.

Prex eucharistica. Textus e variis liturgiis antiquioribus selecti, eds. A. Hänggi, I. Pahl, Fribourg 1968.

Righetti M., Manuale di storia liturgica, vol. 2: L’anno liturgico. Il breviario, Milano 1955. Roszak P., Mozarabowie i ich liturgia. Chrystologia rytu hiszpańsko-mozarabskiego, Toruń 2015.

Sacramentarium Fuldense saeculi x, eds. G. Richter, A. Schönfelder, Fulda 1912.

Sacramentarium Gelasianum, a cura di L. C. Mohlberg, Roma 1960.

Scientia liturgica. Manuale di Liturgia, vol. 3: L'Eucaristia, direzione di A. J. Chupungo, Casale Monferrato 1998.

Teresa od Jezusa, Dzieła, t. 2, przeł. H. P. Kossowski, Kraków 1987.

The Oxford handbook of the Trinity, eds. G. Emery, M. Levering, Oxford 2011.

Wieczerza mistyczna. Anafory eucharystyczne chrześcijańskiego Wschodu, wybór, wstęp, przeł. i przypisy H. Paprocki, Warszawa 1988. 